Jurnal Konstruksi Hukum | ISSN: XXXX | E-ISSN: XXXX Vol. 1, No. 2, Oktober 2020, Hal. 276-280| Available Online at https://www.ejournal.warmadewa.ac.id/index.php/jukonhum DOI: https://doi.org/10.22225/jkh.1.2.2589.276-280

\title{
PENGATURAN TERHADAP PENGUSAHAAN AIR BAWAH TANAH YANG DILAKUKAN OLEH MASYARAKAT
}

\author{
Desak Putu Setyarina, I Pt. Gd. Seputra, Luh Putu Suryani \\ Fakultas Hukum Universitas Warmadewa, Denpasar-Bali, Indonesia
}

\begin{abstract}
Abstrak
Air memiliki peran penting dalam kelangsungan hidup semua makhluk hidup di muka bumi ini. Air bawah tanah adalah termasuk suatu sumber daya alam yang kehadirannya terbatas dan kerusakan yang timbul dapat mengakibatkan dampak yang meluas serta perbaikannya cukup susah. Untuk menjamin penggunaan dan pengusahaan air bawah tanah yang secara adil diperlukan suatu perizinan. Namun dalam penggunaan dan pengusahaan air bawah tanah tersebut masih ada masyarakat serta para pihak industri yang tidak memiliki izin dari pemerintah yang terkait sesuai dengan peraturan Perundang-undangan yang berlaku. Tujuan penelitian ini adalah untuk mengetahui bagaimana pengaturan dari pengusahaan air bawah tanah yang dilakukan oleh masyarakat serta apa akibat hukum dari pengusahaan air di bawah tanah yang tidak memiliki izin. Metode yang dipergunakan dalam penelitian ini adalah metode normatif dan analisis interpretasi hukum serta analisis deskriptif. Sumber data adalah sumber data primer dan sekunder. Pendekatan masalah yang digunakan dalam penelitian ini adalah pendekatan perundang-undangan serta pendekatan analisis konsep hukum. Teknik pengumpulan bahan-bahan hukum yang di lakukan yaitu dengan cara studi pustaka yang selanjutnya setelah bahan hukum terkumpul kemudian diolah menggunakan cara analisis interpretasi sistematis. Hasil penelitian menunjukkan bahwa dalam pengaturan pengusahaan air bawah tanah terdapat kewenangan serta dasar hukum yang digunakan pemerintah sebagai acuan dalam pemberian izin. Kemudian,, akibat dari tidak memiliki izin dalam hal penggunaan air bawah tanah adalah penyegelan lokasi atau tempat dan pengenaan sanksi hukuman pidana penjara sesuai dengan peraturan perundang-undangan yang berlaku yaitu UUNomor 11 Tahun 1974 Tentang Pengairan serta sanksi lainnya sesuai dengan Peraturan Daerah masing-masing.
\end{abstract}

Kata Kunci : Air tanah; Perizinan; Pengusahaan

\begin{abstract}
The water has an important role in survival of all living things on this earth. Water in underground is a natural resources and the damage that occurs can cause widespread impact and repair is quite difficult. In order to guarantee the fair used and exploitation of groundwater, a permit is required. However, in the use and exploitation of groundwater, there are people and industrial parties who did not have a permit from the government related to the prevailing laws and regulations. The purpose of this research is to find out how the regulation of underground water exploitation is carried out by the community and what are the legal consequences of unlicensed underground water exploitation. The method used in this research is normative method and analysis of legal interpretation and descriptive analysis. Data sources are primary and secondary data. The research approach used in this research is an invitation-only approach and a legal concept analysis approach. The technique of conducting legal materials is carried out by means of literature study which is legal materials are collected then processed using systematic interpretation analysis. The results of this research are; firstly, in regulating the exploitation of groundwater, the authority and legal basis used by the government as a reference in granting permits. Second, the result of not having a permit to use ground water is the sealing of the location or place and the imposition of imprisonment in accordance with the applicable laws, namely Law Number 11 of 1974 concerning Irrigation and other regulations in accordance with the respective Regional Regulations.
\end{abstract}

Keywords: Ground water; Licensing; Business 


\section{PENDAHULUAN}

Air merupakan suatu kebutuhan pokok bagi kelangsungan hidup manusia dan mahluk hidup lainnya dan merupakan salah satu sumber daya yang terbatas. Air bawah tanah merupakan sumber daya alam yangadalah termasuk suatu sumber daya alam yang kehadirannya terbatas dan kerusakan yang timbul dapat mengakibatkan dampak yang meluas serta perbaikannya cukup susah untuk dilakukan (Rejekiningrum, 2009). Air bawah tanah memiliki peranan penting dalam penyediaan pasokan kebutuhan air. Untuk berbagai keperluan dan menjadi opsi ke dua bilamana air dipermukaaan yang tersedia telah habis atau tidak dapat mencukupi namun atas dengan persyaratan yaitu agar selalu menmperhatikan upaya pelestarian menlingkupi pencegahan atau penghindaran kehancuran dan kerusakan terhadap lingkungan.

Mengingat peranan air.bawah tanah tersebut, maka penggunaan airbawah tanah harus dijaga, dipelihara dan diawasi secara tepat dan benar. Sesuaipuladengan isi Pasal 33 dalam UUD NRI Tahun 1945 ayat (3) yang mengegaskan bahwa "Bumi dan air dan kekayaan alam yang terkandung di dalamnya dikuasai oleh negara dan dipergunakan untuk sebesar-besar kemakmuran rakyat". Pengelolaan air bawah tanah dan pengawasannya harus dilakukan secara arif bijaksana melihat segi hukum, yaitu peraturan perundang-undangan yang berlaku pada bidang air dibawah tanahjuga pada dari segi teknis yang memuat mengenai penhgetahuan tentang air dibawah tanah pada suatu daerah (Kompasiana, 2015). Dalam menggunakan air bawah tanah tersebut, masyarakat serta para pihak industri masih ada yang tidak memiliki izin dari pemerintah yang terkait. Produk dari kebijakan sebagai suatu funhgsipengawasan atau kontrol saat pemanfataan sumberdaya airtetap ada memperlihatkan suatu kekurangan atau kelemahan. Lumayan susah atau sulitdalam membatasi pergerakkan dari masyarakat dan para pengusaha industri ketika sedang menggunakan air dibawah tanah untuk pilihan alternatif sumber dayanya.

Beberapa contoh kasus mengenai penggunaan air bawah tanah yang tidak memiliki izin, yakni: BS, warga negara asing asal Jerman, Direktur dari PT. Greenland Property Lombok sebuah perusahaan yang bergerak di bidang kontruksiberalamat di Desa Malaka, Pemenang, Lombok Utara ini ditetapkan sebagai tersangka dalam kasus mengenai dugaan pengeboran serta pengolahan air yang tidak sesuai dengan perizinan (ilegal) karena mengelola air dibawah tanah untuk kepentingan komersial. Eksploitasi terhadap air dibawah tanah tersebut berlangsung dari tahun 2012 dicurigai dikomersillkan seharga Rp. 25.000(dua puluh lima puluh ribu rupiah) per 28m (NTB, 2018). Kemudian, sumur Air Bawah Tanah (ABT) milik PT Betania Multisarana di Plaza Ciputat dan PT Kharisma Sentosa di kawasan Mega Mall Ciputat, Kota Tangsel, disegel petugas gabungan dari Pemkot Tangsel. Kedua perusahaan tersebut diduga tidak mengantongi izin pengambilan ABT. Dua perusahaan tersebut mengambil air bawah tanah untuk dikomersialkan kepada pedagang maupun masyarakat di sekitar Pasar Ciputat (Deny Irawan, 2014).

Berdasarkan uraian yang telah dijelaskan diatas, maka penelitian ini dirumuskan untuk mengetahui pengaturan dari pengusahaan air bawah tanah yang dilakukan oleh masyarakat, dan untuk mengetahui akibat hukum dari pengusahaan air di bawah tanah yang tidak memiliki izin.

\section{METODE PENELITIAN}

Penelitian ini menggunakan tipe penelitian normatif (Soekanto \& Mamudji, 2006). Pendekatan masalah yang digunakan dalam menulis penelitian ini diantaranya adalah pendekatanperundangundangan serta pendekatan analisis konsep hukum. Sumber dari bahan hukum yang dipergunakan dalam peneltian ini adalah bahan Hukum Primer, adalah bahan hukum bersifat mengikat dan bersumber dari peraturan perundang-undangan yang berlaku, sebagai berikut: UUD NRI Tahun 1945, UU Tentang Pengairan, UU Tentang Administrasi Pemerintahan, PP Tentang Pembagian Urusan Pemerintahan Antara Pemerintah, Pemerintah Daerah Provinsi dan Pemerinah Daerah Kabupaten atau Kota, PP Tentang Air Tanah, PP Tentang Pengusahaan Sumber Daya Air, Keputusan Menteri ESDM NO: $1451 \mathrm{~K} / 10 / \mathrm{MEM} / 2000$ Tentang Pedoman Teknis Penyelanggaraan Tugas Pemerintahan Di Bidang Pengelolaan Air Bawah Tanah dan Peraturan Gubernur Bali No 5 Tahun 2016 Tentang Perizinan Air Tanah. Kemudian, bahan hukum sekunder, yaitu bahan hukum yang bersumber dari buku serta literatur terkait atas permasalahan yang diangkat yaitumengenai pengusahaan air tanah yang terdiri dari beberapa hasil karya kalangan dunia hukum, laporan, literatur dan jurnal hukum (Muhamad, 2004). Teknik pengumpulan bahan-bahan hukum yang di lakukan yaitu dengan cara studi pustaka yang selanjutnya setelah bahan hukum terkumpul kemudian diolah menggunakan cara 
analisis interpretasi sistematis.

\section{HASIL PENELITIAN DAN PEMBAHASAN}

Pengaturan dari Pengusahaan Air Bawah Tanah yang Dilakukan oleh Masyarakat

Asas Legalitas adalah termasuk salah satu dari prinsip utama digunakan sebagai landasan atau dasar pada setiap penyelanggaraan pemerintahan dan kenegaraan pada setiap negara hukum (Hadjon dkk., 1993). Asas legalitas termasuk dalam penyelanggaran bagian administrasi pemerintahan yang mengutamakan dasar hukum atas sebuah keputusan dan atau sebuah tindakan yang telah dibuat oleh suatu badan dan atau suatu pejabat dari pemerintahan. Penerapan asas legalitas tersebut dapat menunjang berlakunya suatu kepastian hukum dan juga kesamaan dalam mendapat suatu perlakuan. Setiap penyelenggaran dari pemerintahaan dan kenegaraan wajib mempunyai legitimasi dimana kewenangan tersebut diberikan oleh UU (norma wewenang). Jadi esensi dari asas legalitas(legalitiet beginselen) pada penyelengaraan pemerintahan dan kenegaraan adalah "wewenang". Dimana wewenang tersebut adalah sebuah atau suatu kemampuan untuk dapat melakukan perbuatan atau sebuah tindakan-tindakan hukum tertentu. Wewenang adalah sebuah bagian yang penting, karena pemerintah untuk dapat menjalankan fungsinya berdasrkan wewenang yang didapatnya. Dimana yang berarti keabsahan dari tindakan pemerintahan tersebut atas dasar dari wewenang yang telah diatur di dalam peraturan perundang-undangan (legalitiet beginselen). Secara teoretis wewenang dapat diperoleh oleh pemerintah melalui 3 (tiga) cara antara lain: wewenang atribusi, wewenang delegasi dan wewenang mandat.

Pemerintah mempunyai hak dan kewajiban dalam pengelolaan sumber daya air yang kemudian di limpahkan berdasarkan berdasarkan asas otonomi dan tugas pembantuan untuk dapat dilaksanakan bersama dengan pemerintah daerah sesuai dengan ruang lingkup dari wilayah kewenangannya yang berdasarkan dari kewenangan atribusi. Kewenangan pemerintah mengenai pengusahaan dan pengelolaan air tanah atau sumber daya air tecantum di dalam: Undang-Undang Tentang Pengairan, Peraturan Pemerintah Tentang Air Tanah, Keputusan Menteri ESDM Pedoman Teknis Penyelenggaraan Tugas Pemerintah di Bidang Pengelolaan Air Bawah Tanah, PP Pembagian Urusan Antara Pemerintah, PEMDA Prov. dan PEMDA Kab. atau Kota. Dasar Hukum adalah suatu aturan atau ketentuan hukum pada PER-UU-AN (peraturan perundang-undangan) yang dapat menjadi dasar atau landasan bagi setiap penyelenggara pemerintahan atau kenegaran dan subyek hukum baik perorangan maupun yang berbentuk badan hukum. Setiap dalam penyelenggaraan tugas, fungsi dan wewenang bagi lembaga negara haru wajib memiliki dasar atau landasan hukum atau agar tindakan dan penyelanggaraan itu tidak akan bertentangan dengan nilai moral serta etika juga ketentuan dari peraturan perundang-undangan yang sedang berlaku.

Dasar atau landasan hukum pemerintah dalam hal perizinan pengusahaan air tanah adalah, sebagai berikut :

1. UU Republik Indonesia No. 11 Tahun 1974Tentang Pengairan.

2. UU Republik Indonesia No. 28 Tahun 2009 Tentang Pajak Daerah dan Retribusi Daerah.

3. PP No. 42 Tahun 2008 Tentang Pengelolaan Sumber Daya Air.

4. PP No. 43 Tahun 2008 Tentang Air Tanah.

5. PP No. 121 Tahun 2015 Tentang Pengusahaan Sumber Daya Air.

6. PP No. 38 Tahun 2011 Tentang Sungai.

7. Keputusan Menteri ESDM Republk Indonesia No:1451K/10/MEM/2000Tentang Pedoman Teknis Penyelenggaraan Tugas Pemerintahan Dibidang Pengelolaan Air Bawah Tanah.

8. Keputusan Presiden No. 26 Tahun 2011 Tentang Penetapan Cekungan Air Tanah.

9. Peraturan Daerah(PERDA) Provinsi.

10. Peraturan Daerah(PERDA) Kab atau Kota.

Umumnya pemerintah dalam memperoleh atau mendapat wewenang untuk mengeluarkan suatu perizinan tersebut telah ditentukan secara tegas didalam sebuah peraturan perundang-undangan yang menjadi dasar atau landasan dari perizinan seperti yang sudah dijelaskan pada bab sebelumnya. Izin atau perizinan mengenai pengusahaan sumber daya khususnya dalam hal ini adalah air tanah diberikan oleh pemerintah pusat atau pemerintah daerah(PEMDA) sesuai dengan kewenangannya masing-masing. 


\section{Akibat Hukum dari Pengusahaan Air di Bawah Tanah yang Tidak Memiliki Izin}

Dalam hal penggunaaan dan pengusahaan air tanah tersebut haruslah memiliki izin sesuai dengan peraturan perundangan-undangan yang berlaku (Hadjon, 1993). Mengenai perizinan pengusahaan air tanah telah diatur di dalam Peraturan Pemerintah Republik Indonesia Tentang Air Tanahdan dalam Peraturan Pemerintah Tentang Pengusahaan Sumber Daya Air (Sutedi, 2011). Prosedur umum dari Perizinan Pengusahaan Sumber Daya Air, antara lain :

1. Pemohon mengajukan surat permohonan rekomendasi teknis kepada Kepala Dinas Pekerjaan Umum Provinsi c.q. Kepala Bidang Sumber Daya Air dengan membawa persyaratan dan dokumen yang diperlukan sesuai peraturan yang berlaku.

2. Tim rekomendasi teknis Sumber Daya Air melakukan evaluasi awal dan setelah dinyatakan lengkap maka tim rekomendasi siap untuk menyusun Rekomendasi Teknis.

3. Tim rekomendasi teknis Sumber Daya Air melakukan suatu kajian atau penelitianserta evaluasi untuk kelayakan dari permohonan tersebut dan tetap berkoodinasi dengan si Pemohon serta menyusun hasil dari kajian atau penelitian dan evaluasi yang dituangkan pada atau dalam Rekomendasi Teknis.

4. Kepala Dinas Pekerjaan Umum berkoordinasi dengan Kepala Bidang Sumber Daya Air untuk menindaklanjuti Rekomendasi Teknis dan melakukan verifikasi atas Rekomendasi Teknis tersebut. Kemudian berkoordinasi dengan Tim Rekomendasi Teknis Sumber Daya Air.

5. Kepala Dinas Pekerjaan Umum Provinsimenerbitkan surat penyampaian Rekomendasi Teknis kepada Pemohon.

6. Pemohon mengajukan surat permohonan rekomendasi teknis untuk Kepala Badan Penanaman Modal\&Perizinan Terpadu 1 (Satu) Pintu Provinsi.

7. Kepala Badan Penanaman Modal dan Perizinan Terpadu Satu Pintu Provinsi melakukan verifikasi atas permohonan izin tersebut.

8. Kepala Badan Penanaman Modal dan Perizinan Terpadu Satu Pintu Provinsi menggunakan rekomendasi teknis dari Kepala Dinas Pekerjaan Umum Provinsi untuk memutuskan apakah izin tersebut dikembalikan, menolak atau menetapkan izin.

Akibat atau Konsekuensi hukum adalah dimana merupakan suatu kejadian atau peristiwa yang timbul yang disebabkan dari perbuatan yang dilakukan oleh subyek hukum berupa perbuatan yang sesuai dengan norma atau aturan hukum maupun perbuatan yang tidak sesuai dengan norma atau aturan hukum. Dalam permasalahan pengusahaan air bawah tanah yang tidak memiliki izin, akan menimbulkan suatu akibat hukum yaitu berupa penyegelan tempat atau lokasi pengusahaan air bawah tanah dan pengenaan sanksi hukuman pidana penjara yang telah diatur dalam Undang-Undang Republik Indonesia Tentang Pengairan Bab X mengenai Ketentuan Pidana Pasal 15 ayat (1)Serta sanksi-sanksi hukum lainn sesuai dalam Peraturan Daerah (PERDA) yang terdapat di Daerahnya masing-masing.

\section{SIMPULAN SARAN \\ Simpulan}

Dari penjelasan di atas, dapat ditarik beberapa kesimpulan, yaitu: pengaturan dari pengusahaan air bawah tanah yang dilakukan oleh masyarakat telah termuat di dalam peraturan perundang-undangan, diantaranya adalah: Undang-undang Republik Indonesia Nomor 11 Tahun 1974 Tentang Pengairan, UU No. 28 Tahun 2009 Tentang Pajak Daerah dan Retribusi Daerah,PP No. 42 Tahun 2008 Tentang Pengelolaan Sumber Daya Air,PP No. 121 Tahun 2015 Tentang Pengusahaan Sumber Daya Air, Peraturan Pemerintah Nomor 121 Tahun 2015Tentang Pengusahaan Sumber Daya Air, PP No. 38 Tahun 2011 Tentang Sungai, Keputusan Menteri ESDM NO: 1451 K/10/MEM/2000 Tentang Pedoman Teknis Penyelanggaraan Tugas Pemerintahan Di Bidang Pengelolaan Air Bawah Tanah,Keputusan Presiden No. 26 Tahun 2011 Tentang Penetapan Cekungan Air Tanah (CAT), Peraturan Daerah (PERDA) Provinsi dan Peraturan Daerah (PERDA) Kab. atau Kota. Berdasarkan kewenangan atribusi, Pemerintah mempunyai hak dan kewajiban dalampengelolaan dan pengusahaan dan air tanah yang kemudian didelegasikan berdasarkan kepada asas otonomi dan tugas pembantuan untuk dilaksanakan bersama dengan pemerintah daerah sesuai dengan ruang lingkup wilayah kewenangannya. Kemudian, konsekuensi hukum dari pengusahaan air bawah tanah yang tidak memiliki izin adalah dapat berupa penyegelan tempat atau lokasi pengusahaan air bawah tanah dan pengenaan sanksi hukuman pidana penjara sesuai dengan peraturan perundang-undangan yang 
berlaku yaitu Undang-Undang Republik Indonesia No. 11 Tahun 1974 Tentang Pengairan Bab X mengenai Ketentuan Pidana pada Pasal 15 ayat(1) yaitu: "diancam dengan hukuman penjara selamalamanya 2 (dua) tahun dan atau denda setinggi-tingginya Rp. 5.000.000,- (lima juta rupiah)”Serta sanksi--sanksi hukum lainn sesuai dalam Peraturan Daerah(PERDA) yang terdapat di Daerahnya masing-masing.

\section{Saran}

Pemerintah dalam menjalankan kewenangannya harus sesuai dengan peraturan perundang-undangan yang berlaku dan bersikap profesional apabila terjadi suatu permasalahan hukum yang dialami oleh masyarakat dalam kasus pengusahaan air bawah tanah yang tidak memiliki izin. Masyarakat diharapkan untuk lebih memperhatikan kegiatan usaha yang akan dilakukan atau yang sedang dijalankan dan harus memenuhi persyaratan yang telah tercantum di dalam peraturan perundangundangan yang berlaku khususnya dalam hal ini adalah mengenai pengusahaan air bawah tanah.

\section{DAFTAR PUSTAKA}

Deny Irawan. (2014). Komersialkan Air Tanah 2 Perusahaan Di Tangsel Disegel.

Hadjon, P. M. (1993). Pengantar Hukum Perizinan. Surabaya: Yuridika.

Kompasiana, G. (2015). Menjaga Kelestarian Air Menjaga Kehidupan Kita. Retrieved 30 September 2018, from https://www.kompasiana.com/rahab2/5548590f25245a/menjaga-kelestarian-air-adalahmenjagakehidupan-kita?page=all

Hadjon, M. P., Martosoeignjo, R. S. S., Basah, S., Manan, B., Marzuki, H. M. L., Berge, J. B. J. M. ten, ... Stroink, F. A. M. (1993). Pengantar Hukum Administrasi Negara Indonesia. Yogyakarta: Gajah Mada University.

Muhamad, A. (2004). Hukum dan Penelitian Hukum. Jakarta: PT. Citra Aditya Bakti.

NTB, S. (2018). Eksploitasi Air Tanah Mentigi Bay, Direktur PT. GPL Jadi Tersangka.

Rejekiningrum, P. (2009). Peluang Pemanfaatan Air Tanah untuk Keberlanjutan Sumber Daya Air. Jurnal Sumberdaya Lahan, 3(2), 85-96.

Soekanto, S., \& Mamudji, S. (2006). Penelitian Hukum Normatif Tinjauan Singkat. Jakarta: Rajawali Pers.

Sutedi, A. (2011). Hukum Perizinan dalam Sektor Pelayanan Publik. Jakarta: Sinar Grafika. 